\title{
ICP-OES Determination of Some Trace Elements in Herbal Oils Using a Three-Phase Emulsion Method and Comparison with Conventional Methods
}

\author{
Dilek Bakircioglu ${ }^{\mathrm{a}}$, Nukte Topraksever ${ }^{\mathrm{a}}$, Selcuk Yurtsever ${ }^{\mathrm{b}}$, and Yasemin Bakircioglu Kurtulus ${ }^{\mathrm{a}}$,* \\ ${ }^{a}$ Trakya University, Faculty of Science, Department of Chemistry, Edirne, Turkey \\ b Trakya University, Faculty of Science, Department of Biology, Edirne, Turkey
}

\section{INTRODUCTION}

Herbal oils have been used for hundreds of years all over the world because they contain naturally occurring antioxidants and essential elements, and are still used today for dietary and health benefits (1).

Nettle (Urtica dioica L.) is used as a folk medicine in many parts of Turkey due to its antioxidant characteristics for preventing and curing cancer (2). It is also used for diuretic, hypoglycemic, anti-inflammatory, anti-rheumatic and hypertensive conditions (3). In addition, it is an important source of vitamin C $(2,4)$.

Linseed (Linum usitatissimum $L$.), also known as flax seed, contains $40-50 \%$ oil and meal, $23-34 \%$ protein, $4 \%$ ash, $5 \%$ fiber and lignin precursor (5). It is a high source of $\omega-3$ fatty acid, $\alpha$-linolenic acid, short-chain polyunsaturated fatty acids, soluble and insoluble fibers, phytoestrogenic lignans, proteins and antioxidants. The $\alpha$-linolenic acid (ALA) (52\% of total fatty acids) decreases hypercholesterolemia, thrombosis, risk of cancer, mammary and prostate gland anti-inflammatory activity, meno-pausal symptoms and osteoporosis, cardiovascular diseases, and reduces platelet adhesiveness $(6,7)$. Recent studies have confirmed the pharmacological actions and probable use of linseed in the treatment of diseases such as atherosclerosis, cancer, (breast, colon, ovary, and prostate) and Alzheimer's disease (8). In gen-

* Corresponding author.

E-mail: ybakircioglu@trakya.edu.tr

Tel: +90 2842359592

\begin{abstract}
The concentrations of cadmium (Cd), chromium (Cr), copper $(\mathrm{Cu})$, iron $(\mathrm{Fe})$, manganese $(\mathrm{Mn})$, nickel $(\mathrm{Ni})$, lead $(\mathrm{Pb})$, and zinc $(\mathrm{Zn})$ were determined in five (Nettle, Linseed, Pumpkin seed, Sesame, and Chamomile) herbal oil samples, using inductively coupled plasma atomic emission spectrometry (ICP OES) after ultrasonic extraction (UE), wet digestion (WD), and the threephase emulsion method (TPE). The concentrations for $\mathrm{Cd}, \mathrm{Cr}$, $\mathrm{Cu}, \mathrm{Fe}, \mathrm{Mn}, \mathrm{Ni}, \mathrm{Pb}$, and $\mathrm{Zn}$ were found to be $0.037-0.064$, 0.014-0.085, 0.735-1.243, 2.105-19.487, 0.104-0.592, $0.105-1.582,0.025-0.125$, and $1.024-2.583 \mathrm{mg} \mathrm{kg}^{-1}$, respectively. The highest concentrations in the herbal oils were $\mathrm{Cr}, \mathrm{Fe}, \mathrm{Mn}$, and $\mathrm{Zn}$, in linseed oil, $\mathrm{Cd}$ and $\mathrm{Pb}$ in sesame oil, $\mathrm{Cu}$ in nettle oil, and $\mathrm{Ni}$ in chamomile oil, respectively. The three sample preparation methods investigated were compared and it was found that the results of TPE and WD are comparable. The statistical results show that the TPE and WD methods usually give similar results.
\end{abstract}

eral, flax seed oil is used in food products, such as juices, milk and dairy, baked and dried foods, such as muffins, macaroni, etc (7). Linseed oil is also used in a wide range of industrial applications (plastics, paint, paper, textile, etc.) (9).

Pumpkin (Cucurbita pepo L.) seed is dark green in color, very rich in protein (28\%) and fat (55\%). It is used as a salad oil and contains rich-free fatty acids (10). It is a source of phytoestrogens similar to other plant sources such as soy foods, flax seed, sunflower seed, sesame seed, etc. (11). Pumpkin seed oil contains a significant level of the special fatty acid of oleic acid and linoleic acid. The important pharmacological activities of pumpkin seed oil are in slowing the progression of hypertension, potential anti-inflammatory activity in arthritis, and also decreases the formation of stones in the bladder (12). It could be used as an alternative to the expensive olive oil.

Sesame (Sesamum indicum L.) seed is an annual plant, and widely used in human nutrition as oil and for food production (Halaweh, java beans, and salads) (13). It is one of the oldest oil seed crops known, domesticated well over 3000 years ago. Because it contains very high amounts of unsaturated fatty acids and lignan compounds, it has excellent oxidative stability (14-16). Its oil is rich in sesamin and sesamolin and therefore more thermally stable than other vegetable oils (17).

Because it has phytosterols as the predominant sterol, this compound increases oxygen solubility in the oil $(18,19)$. Sesame oil increases plasma gamma-tocopherol and vitamin $\mathrm{E}$ activity, which has potential health benefits against heart disease and cancer. The high amount of polyunsaturated fats helps in the reduction of cholesterol (20).

Chamomile (Matricaria recutita L.) is a member of the Asteraceae family and belongs to a major group of aromatic-medicinal plants. Its flowers contain the essential oil. It also contains several medical substances such as sesquiterpenes, flavonoids, and coumarins (21). 
Because it has anti-inflammatory and spasmolytic effects, it is used to treat some diseases (22). It is also widely used in different types of industrial products such as cleaning materials, cosmetics, medicine, etc. Some researchers report that the essential oil extracted from chamomile has anti-microbial activity, which prevents the generation of some species of bacteria, fungi, and viruses (23). Chamomile oil also exhibits antioxidant activities (24).

The quality criteria of herbal oils and their products is increasing day by day because they contain naturally occurring antioxidants and essential elements (25). The presence of trace elements in herbal oils may catalyze the decomposition of hydroperoxides to free radicals and secondary oxidation products. This can increase the carcinogenic effect by interacting with other food constituents (26) and influence the oxidative stability of oil quality (27). Trace element contamination of herbal oils is a major concern and is due to environmental pollution from industrial and traffic emissions and agricultural activities, use of fertilizers, fungicides, and insecticides.

In this study, the concentrations of some trace elements such as $\mathrm{Cd}$, $\mathrm{Cr}, \mathrm{Cu}, \mathrm{Fe}, \mathrm{Mn}, \mathrm{Ni}, \mathrm{Pb}$, and $\mathrm{Zn}$ in various herbal oil samples (Nettle, Linseed, Pumpkin seed, Sesame seed, and Chamomile) were deter- mined by inductively coupled plasma optical emission spectrometry (ICP-OES) after ultrasonic extraction (UE), wet digestion (WD), and the three-phase emulsion method (TPE). Additionally, sample preparation methods are discussed.

\section{EXPERIMENTAL}

\section{Instrumentation}

Element concentrations were determined using a Varian VistaMPX CCD simultaneous inductively coupled optical emission spectrometer (ICP-OES) (Varian Inc., Victoria, Australia). The operating conditions of the ICP-OES are listed in Table I.

An ultrasonic bath (Bandelin Electronic GmbH, Germany) was used for ultrasonic extraction experiments in the preparation of the herbal oil samples.

A thermostatic bath (A Nüve ST 402, Ankara, Turkey) provided the means to maintain samples at an experimental temperature.

A temperature-controlled water bath (WiseBath WB-22, Daihan Scientific Co., Ltd, South Korea) was employed to perform the threephase emulsion method.

TABLE I

Instrumental Operating Conditions of ICP-OES

\begin{tabular}{ll} 
RF power & $1.00 \mathrm{~kW}$ \\
Plasma flow & $15.0 \mathrm{~L} \mathrm{~min}^{-1}$ \\
Auxiliary flow & $1.5 \mathrm{~L} \mathrm{~min}^{-1}$ \\
Nebulizer flow & $0.75 \mathrm{~L} \mathrm{~min}^{-1}$ \\
Pump rate & $15 \mathrm{rpm}$ \\
Replicates & 3 \\
Replicate read time & $10 \mathrm{~s}$ \\
Elements monitored $(\mathrm{nm})$ & $\mathrm{Cd}(214.4), \mathrm{Cr}(267.7), \mathrm{Cu}(327.4), \mathrm{Fe} \mathrm{(238.2),}$ \\
& $\mathrm{Mn}(257.6), \mathrm{Ni}(231.6), \mathrm{Pb}(220.3), \mathrm{Zn}(213.9)$ \\
\hline
\end{tabular}


trated $\mathrm{HNO}_{3}-\mathrm{H}_{2} \mathrm{O}_{2}(2: 1, \mathrm{v} / \mathrm{v})$ was added and kept standing for 10 minutes at room temperature. Afterwards, they were heated to $80^{\circ} \mathrm{C}$ on a hot plate until digestion of the sample was completed. The digested sample was evaporated, cooled to room temperature, and $5 \mathrm{~mL} 0.2 \mathrm{M} \mathrm{HNO}_{3}$ was added and filtered through a blue filter paper, then made up to $10-\mathrm{mL}$ volume with ultra-pure water before ICPOES analysis. The blanks were prepared in a similar manner without sample.

\section{Metbod B: Ultrasound Extraction (UE)}

Herbal oil samples in the amount of $0.1 \mathrm{~g}$ were placed into 50-mL polypropylene centrifuge conical tubes and $10 \mathrm{~mL}$ of $1 \%$ $\mathrm{HNO}_{3}$ and $0.2 \% \mathrm{HCl}(1: 1)$ solutions were added to every tube. The solution was agitated for 30 seconds employing a vortex mixer. Every tube was put into the ultrasonic water bath and sonicated at $170 \mathrm{~W}$ for 5 minutes. After sonication, the supernatant solution was separated into two parts by centrifugation for 5 minutes at $4000 \mathrm{rpm}$. Determination of the elements was carried out in the aqueous phase. Blanks (without sample) were analyzed for all methods (29).

\section{Method C: Three-Phase Emulsion (TPE)}

The use of a three-phase emulsion step (TPE) for sample preparation was based on a procedure published in previous literature $(30,31)$. In brief, primary emulsion (water-in-oil) was prepared using $2 \mathrm{~mL}$ of the Triton ${ }^{\circledR} \mathrm{X}-114$ (acidic) solution. Then, $2 \mathrm{~mL}$ of herbal oil was added dropwise into the acidic surfactant phase while stirring with a vortex. Emulsification time was fixed at 5 minutes and the temperature kept at $25^{\circ} \mathrm{C}$ during homogenization for all experiments. Then the tube was placed into a water bath at $80{ }^{\circ} \mathrm{C}$ to allow the emulsion breakdown and to separate into three phases: (a) surfactant-rich lower phase (s), (b) oil-rich upper phase (o), and (c) acidic aqueous middle phase $(\mathrm{m})$ which contains the extracted elements (see Figure 1). The middle phase is equal to a total volume of $2 \mathrm{~mL}$. The separated middle phase (about $1.5 \mathrm{~mL}$ ) was transferred into a new tube using a micro-pipette. This step of the TPE method is probably the most important. If phase separation is not performed properly, unclear results will be obtained. The studied element concentration in $1.5 \mathrm{~mL}$, which is higher than recommended by the instrument manufacturer, can be reduced by increasing the dilution volume.

\section{Calibration Procedure and Statistical Analysis}

To conduct quantitative analysis by ICP-OES, calibration was performed daily according to the program options of the apparatus. The acidity and concentration of the standards were kept the same as the sample solutions and were prepared in $1 \% \mathrm{HNO}_{3}$ from the stock solution. The range of calibration curves ( 5 points) for the studied elements over the $0-4.0 \mathrm{mg} \mathrm{L}^{-1}$ concentration range were obtained by

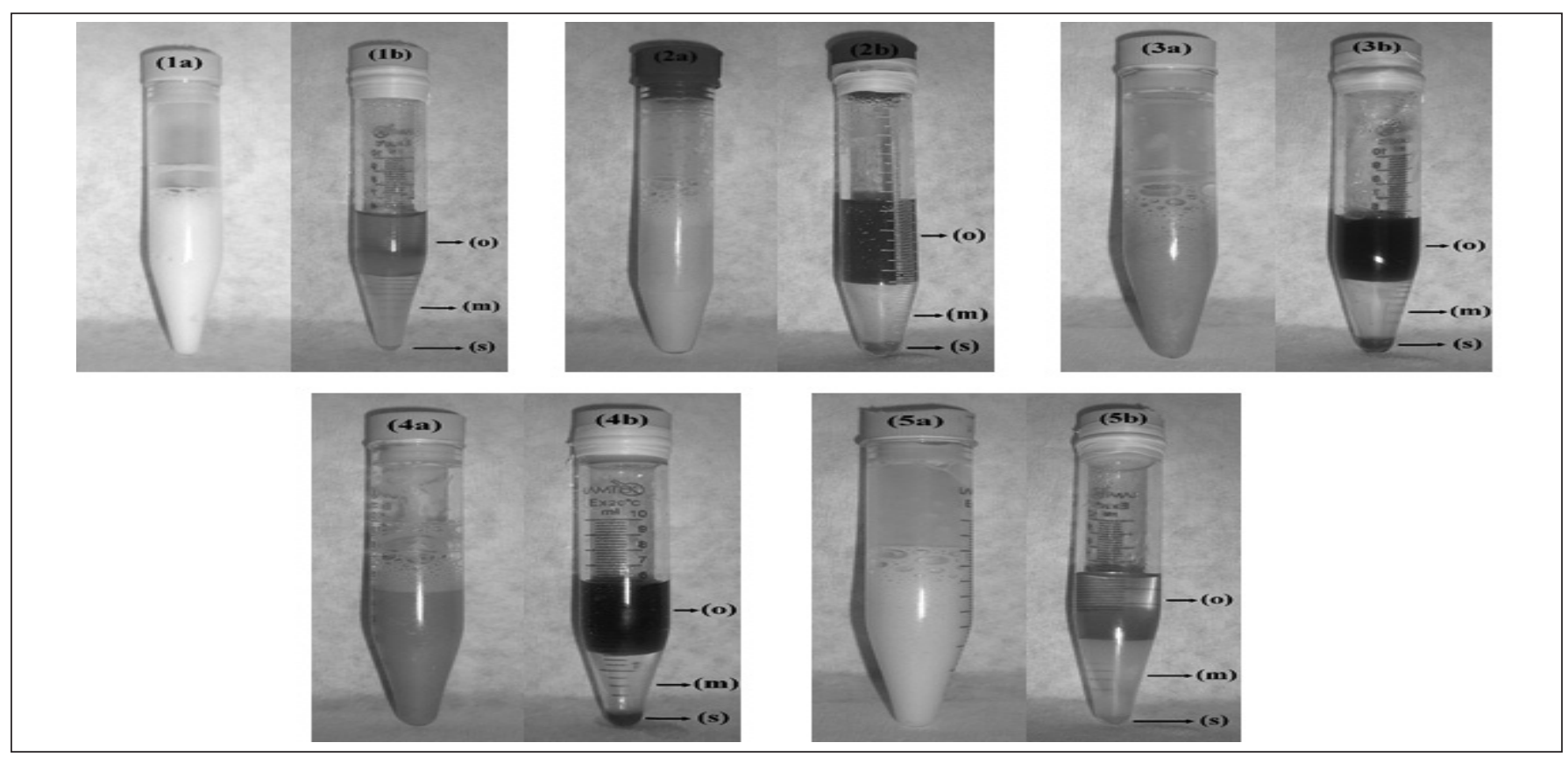

Fig. 1. Emulsion before (1a, 2a, 3a, 4a, 5a) and after breaking by beating at $80^{\circ} \mathrm{C}(1 b, 2 b, 3 b, 4 b, 5 b)$. (o) Herbal oil-rich phase; ( $m$ ) acidic aqueous middle phase; (s) surfactant-rich lower phase. 
ICP-OES. The correlation coefficient of the determination was in the range of 0.9998-0.9999. The statistical significant differences between the concentrations of the trace elements in herbal oil using the various digestion methods were analyzed by ANOVA and determined using by the $\mathrm{P}$ values of $<0.05$. The different results of the statistical evaluation were obtained with the TUKEY test, and the data are expressed as the mean \pm standard deviation (32).

\section{RESULTS AND DISCUSSION}

Herbal oils are the oldest known traditional medicinal products. Their importance is still increasing because many people, particularly in the developing countries, rely on herbal materials for treatment of various ailments, but they are also used in the production of oils and foods. Thus, prevention and detection of contamination are very important criteria for health authorities, pharmaceutical companies, and the population. The study of toxic elements in Turkish herbal oils has to our knowledge never been reported in the literature and should also include the determination of microorganisms, microbial toxins, pesticides, radioactivity (33).

The preparation of herbal materials during their processing includes assessment of the conditions of the starting material, intermediate product or finished product, sampling, packaging, storage, and transport. During these cycles, undesired trace element contamination can occur due to plant types, metal-containing fertilizers, and pesticides $(34,35)$.

In addition, $\mathrm{Fe}, \mathrm{Cu}, \mathrm{Ni}$ and $\mathrm{Mn}$ enhance autoxidation and thus have a significant effect of light on the oil products. On the other hand, $\mathrm{Cr}, \mathrm{Cd}$, and $\mathrm{Pb}$ are very toxic and impact important metabolic functions in humans and animals (36).
In this study, five different herbal oils have been subjected to trace element analysis using ICPOES after UE, WD, and TPE sample preparation (see Tables IIa and IIb). The average $\mathrm{Cd}, \mathrm{Cr}, \mathrm{Cu}, \mathrm{Fe}, \mathrm{Mn}, \mathrm{Ni}$, $\mathrm{Pb}$, and $\mathrm{Zn}$ concentrations were found to be $0.050-0.054,0.018$ 0.080, 0.826-1.155, 2.604-18.548, $0.162-0.508,0.163-1.323,0.033-$ 0.148 and $1.164-2.403 \mathrm{mg} \mathrm{kg}^{-1}$ in herbal oil samples, respectively. For the investigated trace elements, the level of iron was found highest at $18.5,16.5$, and $14.3 \mathrm{mg} \mathrm{kg}^{-1}$ in the linseed, chamomile, and sesame oil samples, respectively, while the concentration of Cr was the lowest at $0.018 \mathrm{mg} \mathrm{kg}^{-1}$ in pumpkin and chamomile. In general, Fe contamination arises from environmental contamination due to mineralization of crops, processing equipment, storage material, and application of agricultural sources (36).

Because of the biological role of $\mathrm{Cr}$, which is related to the carbohydrate, lipid and protein metabolism, it is an essential element for living organisms. Apart from its biological role, the hexavalent form is toxic if taken in excess (37). The concentration of $\mathrm{Cr}$ was about $0.020 \mathrm{mg}$ $\mathrm{kg}^{-1}$, in sesame oil at $0.09 \mathrm{mg} \mathrm{kg}^{-1}$ and linseed oil at $0.080 \mathrm{mg} \mathrm{kg}^{-1}$.

Iron has the following important functions in the human body: (a) as a component of several proteins and enzymes for a healthy immune system; (b) required for the transport of oxygen from tissues to the body for metabolism; (c) acts as pro-oxidant and antioxidant; and (d) decreases the incidence of anemia. Iron deficiency affects growth, results in high menstrual loss, and problems during pregnancy (38). This study shows that the oils of chamomile, sesame, and linseed contain higher amounts of $\mathrm{Fe}$ (14.265 to $18.548 \mathrm{mg} \mathrm{k}^{\mathrm{g}-1}$ ) than all other herbal oils analyzed (2.604 to $6.153 \mathrm{mg} \mathrm{kg}^{-1}$ ).

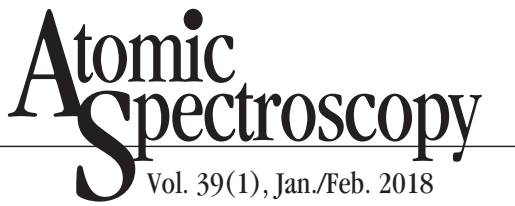

Copper, Fe, and $\mathrm{Mn}$ are directly involved in redox reactions, because they have unpaired electrons which participate in a redox reaction by transferring and accepting electrons or changing the oxidation state. They are essential components of biological systems, which bind to large molecules such as proteins to form mettallo-proteins, and small molecules (phosphates, phytates, polyphenols, and other chelating compounds). Many of the metals in metalloproteins have structural and storage functions, but at the same time they are part of the enzymatic systems. In biological systems, the functions of $\mathrm{Fe}$, $\mathrm{Mn}, \mathrm{Cu}$, and $\mathrm{Zn}$ are to protect human health. Deficiency or inadequate intake of these metals can lead to unwanted pathological problems. It was found that the potential contamination of $\mathrm{Cu}$ and Fe comes from the oil processing equipment, while $\mathrm{Pb}$ and $\mathrm{Cu}$ contamination can be present in oils due to environmental contamination (36).

The concentration of $\mathrm{Mn}$ was in the range of 0.16 to $0.51 \mathrm{mg} \mathrm{kg}^{-1}$. Pumpkin seed had the lowest Mn level and linseed the highest. A sesame seed herbal oil sample differs also from the other oils with regards to its $\mathrm{Pb}$ concentration $\left(0.15 \mathrm{mg} \mathrm{kg}^{-1}\right)$. Copper was found in the range of 0.83 to $0.92 \mathrm{mg} \mathrm{kg}^{-1}$ in all herbal oil samples studied, except for the linseed $(1.02 \mathrm{mg}$ $\left.\mathrm{kg}^{-1}\right)$ and the nettle oil samples (1.15 $\mathrm{mg} \mathrm{kg}^{-1}$ ).

The $\mathrm{Pb}$ and $\mathrm{Cu}$ levels in herbal products were lower than the European pharmacopoeia limits of $\mathrm{Pb}$ at $5 \mathrm{mg} \mathrm{kg}^{-1}$ and $\mathrm{Cu}$ at $150 \mathrm{mg} \mathrm{kg}^{-1}$ (39). Most of the sesame seed oil results are parallel to the results of Juranovic Cindric (35). However, in the present study the $\mathrm{Fe}, \mathrm{Zn}$, and $\mathrm{Ni}$ levels in pumpkin seed oils are lower. Cindric and coworkers (35) found the trace element levels of sesame seed oil at $14.8 \mathrm{mg} \mathrm{kg}^{-1}$ for 
TABLE IIa

The Contents of $\mathrm{Cd}, \mathrm{Cr}, \mathrm{Cu}$, and Fe $\left(\mathrm{mg} \mathrm{kg}^{-1}\right)$ in Five Different Herbal Oils Determined Using Three Different Sample Preparation Methods (Mean \pm SD; $\mathbf{n = 5}$ )

\begin{tabular}{|c|c|c|c|c|c|}
\hline & Sesame & Linseed & Nettle & Pumpkin & Chamomile \\
\hline \multicolumn{6}{|l|}{ Cd } \\
\hline WET & $0.053 \pm 0.007$ & $0.057 \pm 0.006$ (a) & $0.058 \pm 0.009$ (a) & $0.055 \pm 0.005$ (a) & $0.062 \pm 0.010$ (a) \\
\hline UE & $0.048 \pm 0.005$ & $0.035 \pm 0.009$ (b) & $0.034 \pm 0.006(\mathrm{~b})$ & $0.033 \pm 0.004(\mathrm{~b})$ & $0.028 \pm 0.002(b)$ \\
\hline TPE & $0.054 \pm 0.009$ & $0.050 \pm 0.010(\mathrm{ab})$ & $0.053 \pm 0.004(\mathrm{a})$ & $0.051 \pm 0.003$ (a) & $0.052 \pm 0.004$ (a) \\
\hline $\mathrm{P}$ & N.S. & $* * *$ & $* * *$ & $* * * *$ & $* * *$ \\
\hline \multicolumn{6}{|l|}{$\mathrm{Cr}$} \\
\hline WET & $0.089 \pm 0.007$ (a) & $0.055 \pm 0.007$ (a) & $0.038 \pm 0.04(a)$ & $0.022 \pm 0.003$ & $0.109 \pm 0.019$ (a) \\
\hline UE & $0.077 \pm 0.014(\mathrm{ab})$ & $0.037 \pm 0.014(\mathrm{~b})$ & $0.053 \pm 0.008(\mathrm{~b})$ & $0.018 \pm 0.003$ & $0.022 \pm 0.002(b)$ \\
\hline TPE & $0.069 \pm 0.003(b)$ & $0.080 \pm 0.003$ (c) & $0.022 \pm 0.005(\mathrm{c})$ & $0.018 \pm 0.001$ & $0.018 \pm 0.004(b)$ \\
\hline $\mathrm{P}$ & $*$ & $* * * *$ & $* * *$ & N.S. & $* * *$ \\
\hline \multicolumn{6}{|l|}{$\mathbf{C u}$} \\
\hline WET & $0.954 \pm 0.094$ (a) & $0.792 \pm 0.123$ (a) & $1.011 \pm 0.181(\mathrm{a})$ & $0.712 \pm 0.025$ (a) & $1.220 \pm 0.114(a)$ \\
\hline UE & $0.786 \pm 0.035(b)$ & $1.108 \pm 0.050$ (b) & $0.526 \pm 0.043(\mathrm{~b})$ & $0.605 \pm 0.013(\mathrm{~b})$ & $0.871 \pm 0.042(\mathrm{~b})$ \\
\hline TPE & $0.908 \pm 0.013$ (a) & $1.019 \pm 0.08(b)$ & $1.155 \pm 0.077$ (a) & $0.826 \pm 0.078(\mathrm{c})$ & $0.920 \pm 0.87$ (b) \\
\hline $\mathrm{P}$ & $* *$ & $* * *$ & $* * * *$ & $* * * *$ & $* * *$ \\
\hline \multicolumn{6}{|l|}{$\mathbf{F e}$} \\
\hline WET & $17.155 \pm 0.690$ (a) & $27.684 \pm 0.738$ (a) & $6.938 \pm 0.435$ (a) & $3.454 \pm 0.471$ (a) & $28.505 \pm 0.663$ (a) \\
\hline $\mathrm{UE}$ & $8.759 \pm 0.862(b)$ & $11.017 \pm 1.252(\mathrm{~b})$ & $3.211 \pm 0.482(b)$ & $1.203 \pm 0.049$ (b) & $10.160 \pm 0.455$ (b) \\
\hline TPE & $14.265 \pm 0.447$ (c) & $18.548 \pm 0.673$ (c) & $6.153 \pm 0.923$ (a) & $2.604 \pm 0.393$ (c) & $16.553 \pm 0.762(\mathrm{c})$ \\
\hline $\mathrm{P}$ & $* * *$ & $* * *$ & $* * *$ & $* * *$ & $* * * *$ \\
\hline
\end{tabular}

SD: standard deviation.

N.S.: not significant at 0.05 levels.

*, **, ****: indicate significance levels beyond the $0.05,0.01$, and 0.001 levels.

(a),(b),(c): indicate whether compared means are same or not.

Fe, $3.1 \mathrm{mg} \mathrm{kg}^{-1}$ for $\mathrm{Zn}, 0.56 \mathrm{mg} \mathrm{kg}^{-1}$ for $\mathrm{Cu}$, and $0.30 \mathrm{mg} \mathrm{kg}^{-1}$ for $\mathrm{Ni}$. These values were close to the results of this study. The elements $\mathrm{Mn}, \mathrm{Cr}$, and $\mathrm{Pb}$ cannot be compared because the concentrations found by Cindric et al. are below the detection limit. No data have been published with regard to trace elements in edible herbal oils.

The metals $\mathrm{Cd}, \mathrm{Ni}$, and $\mathrm{Pb}$ are known to cause a decrease of some essential nutrients in the cells, and result in diseases such as decrease in immunological defenses, intrauterine growth retardation, psycho-social dysfunctions, and gastrointestinal cancer. Cadmium, which is a highly toxic element, can cause damage even in small amounts to the arteries, kidneys, and the liver. These metals may enter the food chain from soils consisting of sludge, composts, or phosphate-containing fertilizers. For this reason, these products must be used carefully such as cadmium-containing fertilizers (37). The concentration of $\mathrm{Cd}$ in the analyzed oil samples was about 0.050 $\mathrm{mg} \mathrm{kg}^{-1}$ which is lower than the daily recommended intake (DRI) value listed by FAO/WHO (40).

The state of $\mathrm{Zn}^{2+}$ prevents participation in redox reactions. Nevertheless, it acts as an antioxidant by replacing metals that are active in catalyzing free radical reactions, such as Fe (39). The chamomile, pumpkin seed, and linseed oil sam- ples contain higher amounts of $\mathrm{Zn}$ (2.0 to $2.4 \mathrm{mg} \mathrm{kg}^{-1}$ ) compared to the other oils ( 1.16 to $1.35 \mathrm{mg} \mathrm{kg}^{-1}$ ). $\mathrm{Ni}$ was found in the range of 0.163 to $0.402 \mathrm{mg} \mathrm{kg}^{-1}$ in all herbal oil samples, except the chamomile oil (1.323 $\mathrm{mg} \mathrm{kg}^{-1}$ ).

The Joint FAO/WHO Expert Committee on Food Additives, Environmental Protection Agency (EPA), and the US National Council (NRC) have set a limit for metal intake based on body weight. For an adult, the daily recommended intake (DRI) values of $\mathrm{Cd}, \mathrm{Cr}, \mathrm{Cu}$, $\mathrm{Fe}, \mathrm{Mn}, \mathrm{Ni}, \mathrm{Pb}$, and $\mathrm{Zn}$ were reported as $0.07 \mathrm{mg}, 1.5 \mathrm{mg}, 0.9$ $\mathrm{mg}, 48 \mathrm{mg}, 9.8 \mathrm{mg}, 1.4 \mathrm{mg}, 0.25$ $\mathrm{mg}$, and $15 \mathrm{mg}$, respectively (4044). The results of this study show 


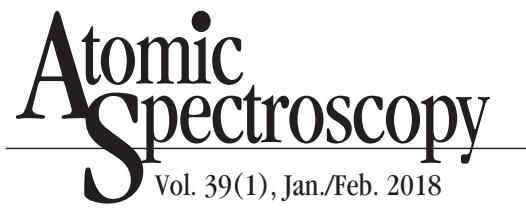

TABLE IIb

The Contents of $\mathrm{Mn}, \mathrm{Ni}, \mathrm{Pb}$, and $\mathrm{Zn}\left(\mathrm{mg} \mathrm{kg}^{-1}\right)$ in Five Different Herbal Oils Determined Using Three Different Sample Preparation Methods (Mean $\pm S D ; n=5)$

\begin{tabular}{|c|c|c|c|c|c|}
\hline & Sesame & Linseed & Nettle & Pumpkin & Chamomile \\
\hline \multicolumn{6}{|l|}{ Mn } \\
\hline WET & $0.339 \pm 0.013$ (a) & $0.555 \pm 0.064(a)$ & $0.193 \pm 0.043(\mathrm{a})$ & $0.161 \pm 0.024(a)$ & $0.378 \pm 0.850$ (a) \\
\hline UE & $0.042 \pm 0.012(\mathrm{~b})$ & $0.053 \pm 0.008(\mathrm{~b})$ & $0.011 \pm 0.002(\mathrm{~b})$ & $0.004 \pm 0.0004$ (b) & $0.006 \pm 0.007$ (b) \\
\hline TPE & $0.342 \pm 0.036$ (a) & $0.508 \pm 0.070(\mathrm{a})$ & $0.179 \pm 0.042(\mathrm{a})$ & $0.162 \pm 0.038$ (a) & $0.366 \pm 0.020(a)$ \\
\hline $\mathrm{P}$ & $* * *$ & $* * *$ & $* * *$ & $* * *$ & $* * *$ \\
\hline \multicolumn{6}{|l|}{$\mathbf{N i}$} \\
\hline WET & $0.541 \pm 0.061$ (a) & $2.427 \pm 0.133$ (a) & $0.338 \pm 0.064(a)$ & $1.186 \pm 0.081$ (a) & $1.333 \pm 0.128$ (a) \\
\hline UE & $0.305 \pm 0.071(\mathrm{~b})$ & $1.090 \pm 0.078(\mathrm{~b})$ & $0.649 \pm 0.048(\mathrm{~b})$ & $0.556 \pm 0.042(\mathrm{~b})$ & $0.384 \pm 0.027$ (b) \\
\hline TPE & $0.402 \pm 0.056(\mathrm{~b})$ & $0.256 \pm 0.047(\mathrm{c})$ & $0.163 \pm 0.051(\mathrm{c})$ & $0.172 \pm 0.022(\mathrm{c})$ & $1.323 \pm 0.173$ (a) \\
\hline $\mathrm{P}$ & $* * *$ & $* * *$ & $* * *$ & $* * *$ & $* * *$ \\
\hline \multicolumn{6}{|l|}{$\mathbf{P b}$} \\
\hline WET & $0.149 \pm 0.009$ (a) & $0.062 \pm 0.029(\mathrm{ab})$ & $0.041 \pm 0.017$ (a) & $0.093 \pm 0.006$ (a) & $0.116 \pm 0.015$ (a) \\
\hline $\mathrm{UE}$ & $0.046 \pm 0.009$ (b) & $0.037 \pm 0.010(a)$ & $0.024 \pm 0.007(b)$ & $0.039 \pm 0.006(\mathrm{~b})$ & $0.080 \pm 0.010(\mathrm{~b})$ \\
\hline TPE & $0.148 \pm 0.256$ (a) & $0.088 \pm 0.008(\mathrm{~b})$ & $0.033 \pm 0.006(b)$ & $0.050 \pm 0.005(\mathrm{c})$ & $0.038 \pm 0.004$ (c) \\
\hline $\mathrm{P}$ & $* * *$ & $* * *$ & N.S. & $* * *$ & $* * *$ \\
\hline \multicolumn{6}{|l|}{ Zn } \\
\hline WET & $1.407 \pm 0.113$ (a) & $5.905 \pm 0.303$ (a) & $1.075 \pm 0.142(\mathrm{a})$ & $2.045 \pm 0.133$ & $2.043 \pm 0.111(\mathrm{a})$ \\
\hline $\mathrm{UE}$ & $2.277 \pm 0.087$ (b) & $3.935 \pm 0.385$ (b) & $1.537 \pm 0.094(b)$ & $2.329 \pm 0.111$ & $3.111 \pm 0.68$ (b) \\
\hline TPE & $1.354 \pm 0.101$ (a) & $2.403 \pm 0.196(c)$ & $1.164 \pm 0.116(\mathrm{a})$ & $1.996 \pm 0.566$ & $2.254 \pm 0.157$ (c) \\
\hline $\mathrm{P}$ & $* * *$ & $* * *$ & $* * *$ & N.S. & $* * *$ \\
\hline
\end{tabular}

SD: standard deviation.

N.S.: not significant at 0.05 levels.

*, **, ***: indicate significance levels beyond the $0.05,0.01$, and 0.001 levels.

(a),(b),(c): indicate whether compared means are same or not.

that the mean values of the elements determined were in accordance with the dietary recommended intake (DRI) limits given by FAO/WHO, EPA, and NRC.

The mean values of herbal oils obtained from the five different samples (five replicates for each treatment) using the three different methods are comparable indeed. As can be seen in Tables IIa and IIb, 37 of the 40 ANOVA tests are significant statistically and only three tests reveal no sign of difference. The three methods showed significant statistical different results in a total of 15 cases. The pair-wise comparisons using the posterior TUKEY test clearly reveal that the UE method is comparable to the two other methods of WD and TPE. In most of the treatments, the UE method resulted in lower mean values than the WD and TPE methods. Although the mean value of the WD method was higher than of TPE and UE in most cases, and 14 of the pair-wise comparisons for WD and TPE showed no sign of difference. Accordingly, it can be presumed that the TPE method is preferred over the WD and UE methods. The mean values obtained from TPE were significantly the same as the conventionally used wet digestion methods.

\section{CONCLUSION}

This study presents the results in the determination of elements in nettle seed, linseed, pumpkin seed, sesame seed, and chamomile oil samples by inductively coupled plasma optical emission spectrometry (ICP-OES) after ultrasonic extraction (UE), wet digestion (WD), and the three-phase emulsion (TPE) method. The highest concentration of iron was found in the linseed, chamomile, and sesame oil samples, whereas the chromium concentration was minimum in pumpkin seed and chamomile oil samples. Contamination of herbal materials with metals can be attributed to environmental pollution (i.e., factories, contaminated water, pesticides), soil composition and fertilizers, and the external conditions during the growing seasons, harvesting, and the manufacturing 
process. The most important advantages of this TPE method for the quantitative analysis are the simultaneous determination of many trace elements by ICP-OES, determination in a wide concentration range, simple and fast sample preparation, excellent and effective, less timeconsuming, no use of large amounts of concentrated reagents and no contamination. It is an alternative method to the WD method with much lower equipment cost than the conventional WD and UE methods.

The results with the proposed TPE method were comparable to those obtained after the sample preparation by WD digestion and UE method. The 36 out of 40 ANOVA tests are statistically significant for the three methods. Moreover, the pair-wise comparisons (Turkey) show that 17 tests are not different from WD and TPE and usually give similar results. On the other hand, TPE and UE usually give different results, because the 29 statistical tests were different. Therefore, the TPE method is recommended as an alternative approach to the conventional sample pretreatment method of wet digestion.

\section{ACKNOWLEDGMENT}

This work was supported by the Trakya University Research Fund with Project Number (TUBAP2012/114).

Received October 17, 2016

Revision received September 20, 2017.

\section{REFERENCES}

1. S. Uluata and N. Özdemir, J. American Oil Chemists Soc. 89, 551 (2012).

2. D. Ozyurt, B. Demirata, and R. Apak, Talanta 71, 1155 (2007).

3. A.E. Ince, S. Sahin, and G. Sumnu, J. Food Science Techn. 51, 2776
(2014).

4. K. Al-Ismail, S.M. Herzallah, and A.S. Rustom, Italian J. Food Sci. 19, 287 (2007).

5. K. Mueller, P. Eisner, Y. YoshieStark, R. Nakada, and E. Kirchhoff, J. Food Eng. 98, 453 (2010).

6. B.D. Oomah, J. Sci. Food Agric. 81, 889 (2001).

7. A. Goyal, V. Sharma, N. Upadhyay, S. Gill, and M. Sihag, J. Food Sci. Technol 51, 1633 (2014).

8. Z.A. Salama, A.A Gaafar, and D.M. El-Hariri, J. Nat. Fibers 9, 277 (2012).

9. B. McKevith, Nutr. Bull. 30, 13 (2005).

10. D. Joebstl, D. Bandoniene, T. Meisel, and S. Chatzistathis, Food Chem. 123, 1303 (2010).

11. S. Patel, Med. J. Nutrition Metab. 6, 183 (2013).

12. F. Shahidi, Bailey's Industrial Oil and Fat Products, 6 Volume Set, 6th Edition, Volume 3: L.L. Yu, J.W. Parry, and Z. Kequan) University of Maryland College Park, Maryland, USA,. 233 (2005).

13. M. Elleuch, S. Besbes, O. Roiseux, C. Blecker, and H. Attia, Food Chem. 103, 641 (2007)

14. E.Choe, and D.B. Min, Comp. Rev. Food Sci. Food Saf. 5, 169 (2006).

15. I.E. Milder, I.C. Arts, B. van de Putte, D.P. Venema, and P.C. Hollman, Br. J. Nutr. 93, 393 (2005).

16. P.C. Kuo, M.C. Lin, G.F. Chen, T.J. Yiu, and J.T.C Tzen, J. Agric. Food Chem. 59, 3214 (2011).

17. L. Prado-Silva, L. Azevedo, J.A.C. Oliveira, A.P.M. Moreira, M. Schmiele, Y.K. Chang, F.B.A. Paula, and M.T.P.S Clerici, Food Res. Inter. 62, 609 (2014).

18. M. Dachtler, F.H.M. van de Put, F.V. Stijn, C.M. Beindorff, and J. Fritsche, Eur. J. Lipid Sci. Tech. 105, 488 (2003).

19. N. Yanishlieva, and H. Schiller, J. Sci. Food Agric. 35, 219 (1984).

20. S. Protonotariou, V. Evageliou, S. Yanniotis, and I. Mandala, J. Food Eng. 117, 124 (2013).

21. I. Stancheva, M. Geneva, M.
Boychinova, I. Mitova, and Y. Markovska, J. Plant Nut. 37, 1952 (2014).

22. S. Chand, A. Pandey, and D.D. Patra, Water, Air and Soil Pollut. 223, 2257 (2012).

23. S. Petronilho, M. Maraschin, M.A. Coimbra, and S.M. Rocha, Ind. Crop Prod 40, 1 (2012).

24. D.L. McKay, and J.B. Blumberg, Phyto Res 20, 519 (2006).

25. H.A. Gad, S.H. El-Ahmady, M.I. Abou-Shoer, and M.M. Al-Azizi, Phytochem. Anal. 24, 1 (2013).

26. A. Szydlowska-Czerniak, K. Trokowski, G. Karlovits, and E. Szlyk, J. Agric. Food Chem. 61, 2276 (2013).

27. I. Juranovic, P. Breinhoelder, and I. Steffan, J. Anal. At. Spec. 18, 54 (2003).

28. R. Ansari, T.G. Kazi, M.K. Jamali, M.B. Arain, M.D. Wagan, N. Jalbani, H.I. Afridi, and A.Q. Shah, Food Chem. 115, 318 (2009).

29. F. Camin, R. Larcher, M. Perini, L. Bontempo, D. Bertoldi, G. Gagliano, G. Nicolini, and G. Versini, Food Chem. 118, 901 (2010).

30. D. Bakircioglu, Y.B. Kurtulus, and S. Yurtsever, Food Chem. 138, 770 (2013).

31. R.J. Cassella, D.M. Brum, C.E.R. de Paula, and C.F. Lima, J. Anal. At. Spectrom. 25, 1704 (2010).

32. R.R. Sokal, and F.J. Rohlf, Biometry, W.H. Freeman and Company, New York, USA, pp. 887 (Third Edition) (1995).

33. M. Mosihuzzaman, and M.I. Choudhary, Pure Appl. Chem. 80, 2195 (2008).

34. WHO guidelines for Good Manufacturing Practices (GMP) for herbal medicines. Geneva, Swirzerland, World Health Organization (2007).

35. I.J. Cindric, M. Zeiner, and I. Steffan, Microchem. J. 85:136-139 (2007).

36. D. Mendil, Ö.D. Uluözlü, M. Tüzen, and M. Soylak, J. Hazard. Mat. 165, 724 (2009).

37. I.O. Akinyele, and O.S. Shokunbi, 


\section{A Spectroscopy $_{\text {pec }}^{\text {tom }}$ \\ 1 Vol. 39(1), Jan./Feb. 2018}

Food Chem. 173, 702 (2015).

38. C.G. Fraga, Mol. Aspects Med. 26, 235 (2005).

39. Herbal drugs monograph 1433 Pharmeuropa 20, 302 (2008).

40. World Health Organization. Trace Elements in human nutrition and health. ISBN: 9241561734 (NLM Classification: QU 130) (1996).

41. World Health Organization. Evaluation of certain food additives and contaminants. Forty-first report of the joint $\mathrm{FAO} / \mathrm{WHO}$ expert committee on food additives, WHO Tecnical series no. 837. Geneva, Switzerland (1993).

42.. World Health Organization. Evaluation of certain food additives and contaminants. Thirty-third report of the joint $\mathrm{FAO} / \mathrm{WHO}$ expert committee on food additives, WHO Technical series no. 837, Geneva, Switzerland (1989).

43. EPA. Environmental Protection Agency, 2001 Integrated Risk Information System. IRIS from US: Available at

http://www.epa.govyirisygloss8.ht m) (Access on 29, October 2001).

44. NRC, Recommended Dietary Allowances, National Research Council (US) Sub-committee. Washington, DC, USA: National Academy Press (1989); pp. 241. 